\title{
PHYTOCHEMICALS ANALYSIS AND IMMUNOMODULATORY ACTIVITY OF Saurauia vulcani Korth. LEAVES EXTRACTS TOWARDS RAW 264.7 CELL
}

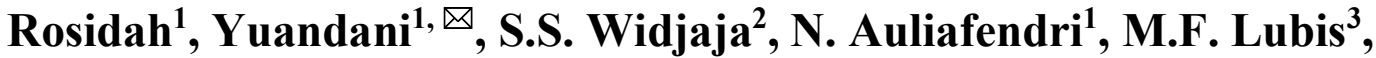 \\ M. Muhammad ${ }^{3}$, and D. Satria ${ }^{4}$ \\ ${ }^{1}$ Department of Pharmacology, Faculty of Pharmacy, Universitas Sumatera Utara, Medan, 20155 \\ ${ }^{2}$ Department of Biochemistry, Faculty of Medicine, Universitas Sumatera Utara, Medan, 20155 \\ ${ }^{3}$ Department of Pharmaceutical Biology, Faculty of Pharmacy, Universitas Sumatera Utara, \\ Medan, 20155 \\ ${ }^{4}$ Department of Pharmaceutical Chemistry, Faculty of Pharmacy, Universitas Sumatera Utara, \\ Medan, 20155. \\ ${ }^{\circledR}$ Corresponding Author: yuandani@usu.ac.id
}

\begin{abstract}
Saurauia vulcani Korth. is an actinidiaceae family plant that is used as traditional medicine by the community. The immunomodulatory effect of Saurauia vulcani Korth. extracts were assessed using in vitro method on RAW 264.7 cells line by stratified extraction using $n$-hexane, ethyl acetate, and ethanol solvents. The viability of cells was determined with the MTT method. Determination of nitric oxide levels was assessed by the griess method and inhibition of gene expression TNF- $\alpha$, IL-6, COX-2, IL-1 $\beta$, and iNOS were determined by the RT-PCR method. Saurauia vulcani Korth. leaves (n-hexane, ethyl acetate, and ethanol) extracts at a concentration of $25 \mu \mathrm{g} / \mathrm{mL}$ were effected to reduce the level of nitric oxide in RAW 246.7 cells and was inhibited the expression of genes TNF- $\alpha$, IL6 , COX-2, IL-1 $\beta$, and iNOS. The density value of each band formed by $1.21 \pm 0.005 ; 1.15 \pm 0.005 ; 0.88 \pm 0.003$ on TNF- $\alpha, 1.23 \pm 0.003 ; 1.64 \pm 0.005 ; 0.55 \pm 0.003$ on IL- $6,0.38 \pm 0.003 ; 0.55 \pm 0.003 ; 0.38 \pm 0.003$ on COX- $2,0.18 \pm$ $0.003 ; 0.04 \pm 0.003 ; 0.03 \pm 0.003$ on IL- $1 \beta$, and $0.30 \pm 0.003 ; 0.41 \pm 0.003 ; 0.11 \pm 0.005$ on iNOS. Extracts could reduce NO production and inhibit gene expressions such as TNF- $\alpha$, IL-6, COX-2, IL-1 $\beta$, and iNOS.
\end{abstract}

Keyword: Saurauia vulcani Korth, Extract, Immunomodulatory, RAW 246.7 Cell Line

RASĀYAN J. Chem., Vol. 14, No.2, 2021

\section{INTRODUCTION}

Immune system dysfunction is responsible for various diseases like arthritis, ulcerative colitis, asthma, allergy, parasitic diseases, cancer, and infectious diseases. ${ }^{1}$ One type of cell that plays a role in the process of immune system activity is macrophage cells. ${ }^{2}$ Macrophages can be activated by microbial components, such as endotoxin, lipopolysaccharides (LPS), and lipoteichoic acids (LTA). Activated macrophages phagocytize micro-organisms, release pro-inflammatory cytokines and nitric oxide (NO), and present antigens to helper $\mathrm{T}$ cells. These cytokines contribute to defense mechanisms of the host immunity in response to the external invasion, but they may induce immuno-pathological disorders when secreted in excess. $^{3}$

Pharmacological of Saurauia vulcani Korth activities such as antihyperglycemic and traditionally used as an anti-inflammatory cannot be separated from the content of secondary metabolites in this plant. ${ }^{4}$ Secondary metabolite compounds such as steroid/triterpenoid, tannin, and flavonoid are found in this plant are the basis for their development as immunomodulators. ${ }^{5}$ Testing the immunomodulatory effect is done in vitro on RAW 246.7 cells line. Determination of nitric oxide levels and inhibition of gene expression of TNF- $\alpha$, IL-6, COX-2, IL- $1 \beta$, and iNOS become a way to determine the immunomodulatory activity of the extracts.

\section{EXPERIMENTAL}

Fresh Saurauia vulcani Korth leaves were collected from Tiga Lingga village, Dairi regency, Sumatera Utara province, Indonesia. RAW 264.7 cells were obtained from Parasitology Laboratory, Faculty of 
RASĀYAN J. Chem.

Vol. 14 | No. 2 |1378-1383| April - June | 2021

Medicine, Gadjah Mada University. The cells were maintained in Dulbecco's modified Eagle's medium (DMEM) supplemented with $10 \%$ Fetal bovine serum and kept at $37^{\circ} \mathrm{C}$ with a $\mathrm{CO}_{2}$ supply of $5 \%$. Lipopolysaccharides are from Escherichia coli O111.B4 (Sigma), Dexamethasone (Harsen), n-hexane, ethylacetate, ethanol 96\%. TLC Silica gel $60 \mathrm{~F}_{254}$ (Merck). All chemicals and reagents used in this work were of analytical grade. Total RNA Mini Kit (Geneaid), ReverTra Ace (Toyobo), GoTaq ${ }^{\circledR G r e e n}$ (Promega), Nuclease-Free Water (Promega), TBE (Vivantis), agarose gel (Promega), Flurosafe (Smobio), DNA ladder 100 bp (Smobio).

\section{Preparation Extract of Saurauia vulcani Korth Leaves}

The powder of Saurauia vulcani Korth leaves $(1 \mathrm{~kg})$ was repeatedly extracted by maceration with $\mathrm{n}$-hexane $(3 \times 3$ day, $10 \mathrm{~L})(\mathrm{NESVL})$. The powder was dried in the air and extracted with ethyl acetate $(3 \times 3$ day, 10 L) (EAESVL) and then the powder was dried in the air and extracted with ethanol ( $3 \times 3$ day, $10 \mathrm{~L})$ (EESVL) at $25-30^{\circ} \mathrm{C}$ with periodical stirring. The filtrate was collected, and then evaporated to obtain a viscous fraction and then freeze-dried to dry $(6,7,8)$.

\section{Phytochemical Screening}

Phytochemical screening of secondary metabolites using standard procedures. ${ }^{9-11}$

\section{Cell Culture and Cell Viability}

RAW 264.7 cells were grown in Dulbecco's Modified Eagle's Medium (DMEM) containing 10\% fetal bovine serum, 100 units $/ \mathrm{mL}$ of penicillin, and $100 \mu \mathrm{g} \mathrm{mL}^{-1}$ of streptomycin. Cells were incubated in the presence of $5 \% \mathrm{CO}_{2}$ at $37^{\circ} \mathrm{C}$. The cells (passage 7-12) were seeded at a concentration of $3 \times 10^{3}$ cells in $0.1 \mathrm{~mL}^{-1}$ in $96-$ well plates and incubated $24 \mathrm{~h}$. The effects of Saurauia vulcani Korth leaves extracts on cell viability were evaluated with the 3-(4,5-dimethyl-2-thiazolyl)-2,5-diphenyl-2H-Tetrazolium Bromide (MTT) colorimetric assay (Sigma-Aldrich). Extracts of Saurauia vulcani Korth leaves were dissolved in $100 \% \mathrm{DMSO}$, and the stock solution of the extract at a concentration of $50.000 \mu \mathrm{gmL}^{-1}$ was prepared in DMSO. The final concentrations of the extract ranged from $1-200 \mu \mathrm{gmL}^{-1}$ in the culture media. Dexamethasone and lipopolysaccharides were used as positive and negative controls. ${ }^{12}$

\section{Nitrite Oxide (NO) Production Activity}

The cells were seeded at a concentration of $3 \times 10^{3}$ cells in $0.1 \mathrm{~mL}^{-1}$ in 96 -well plates and incubated $24 \mathrm{~h}$. The effects of Saurauia vulcani Korth leaves extracts with various concentrations of the extract prepared in DMSO and incubated under light at room temperature for $15 \mathrm{~min}$. The same reaction mixture without the tested extract, but the equal amount of the solvent serves as the control (the last well). After the incubation, $0.05 \mathrm{~mL}$ of Griess reagent (1\% sulfanilamide, $2 \% \mathrm{H}_{3} \mathrm{PO}_{4}$, and $0.1 \% \mathrm{~N}-(1-$ naphthyl) ethylenediamine dihydrochloride was added. The absorbance was measured at $540 \mathrm{~nm}$ and the percentage of NO radical inhibition by the extract was calculated from the formula equation: [(A0-A1)/A0] $\times 100$. Where $\mathrm{A} 0$ is the absorbance of the control, and $\mathrm{A} 1$ is the absorbance of the extract/standard. ${ }^{20} \mathrm{The} \mathrm{IC}_{50}$ value was obtained by drawing the equation of the line from the graph of concentration $(\mu \mathrm{g} / \mathrm{mL})$ versus percentage of inhibition. ${ }^{3}$

\section{Reverse Transcription-Polymerase Chain Reaction (RT-PCR)}

The gene expression of TNF- $\alpha$, IL-6, IL-1 $\beta$, iNOS, and COX-2 was determined by RT-PCR. Total RNA from the control cell, LPS, positive control, and treatment groups were extracted using the Total RNA Mini Kit (Geneaid) according to the manufacturer's protocol. The oligonucleotide primers for TNF- $\alpha$, IL-6, IL$1 \beta$, iNOS, COX-2, and $\beta$-actin were designed according to a PCR primer selection program at the website of the Virtual Genomic Center from the GenBank database (Table-1).

PCR has consisted of 35 amplification cycles and each cycle carried out for $30 \mathrm{~s}$ at $95^{\circ} \mathrm{C}, 1 \mathrm{~min}$ at annealing temperature $\left(55^{\circ} \mathrm{C}\right.$ for TNF- $\alpha$, IL-6, COX-2 and beta-actin and $60^{\circ} \mathrm{C}$ for iNOS) and $45 \mathrm{~s}$ at $95^{\circ} \mathrm{C}, 1 \mathrm{~min}$ at annealing temperature $62.5^{\circ} \mathrm{C}$ for IL-1 $\beta$.) and $1 \mathrm{~min}$ at $72^{\circ} \mathrm{C}$ in a thermal cycler (ProFlex ${ }^{\mathrm{TM}} 3 \times 32$-well PCR System, Applied Biosystems). The $\beta$-actin was used as an internal control to standardize the relative expression levels for all biomarkers. PCR products were separated electrophoretically on a $2 \%$ agarose and fluorosafe (Smobio) with Tris-Borate-EDTA (Vivantis) $0.5 x$. The stained gel was visualized by using GelDoc Quantity One software (Syngene) (13). 
RASĀYAN J. Chem.

Vol. 14 | No. 2 |1378-1383| April - June | 2021

Table-1: Mouse Oligonucleotide Primers Sequences Used for RT-PCR (5-3') and Annealing Temperature

\begin{tabular}{|c|c|c|c|c|}
\hline \multicolumn{2}{|c|}{ Gen } & Primer Sequences & Size (bp) & Temp $\left({ }^{\circ} \mathrm{C}\right)$ \\
\hline TNF- $\alpha$ & $\begin{array}{l}\mathrm{F} \\
\mathrm{R}\end{array}$ & $\begin{array}{c}\text { 5'-TGTGCCGCCGCTGTCTGCTTCACGCT-3' } \\
\text { 5'-GATGAGGAAAGACACCTGGCTGTAGA-3' }\end{array}$ & 374 & 55 \\
\hline IL-6 & $\begin{array}{l}\mathrm{F} \\
\mathrm{R}\end{array}$ & $\begin{array}{l}\text { 5'-GATGCTACCAAACTGGATATAATC-3' } \\
\text { 5'-GGTCCTTAGCCACTCCTTCTGTG-3' }\end{array}$ & 269 & 55 \\
\hline IL-1 $\beta$ & $\begin{array}{l}\mathrm{F} \\
\mathrm{R}\end{array}$ & $\begin{array}{l}\text { 5'-CCCTGCAGCTGGAGAGTGTGGA-3' } \\
\text { 5'-TGTGCTCTGCTTGTGAGGTGCTG-3', }\end{array}$ & 447 & 62.5 \\
\hline iNOS & $\begin{array}{l}\mathrm{F} \\
\mathrm{R}\end{array}$ & $\begin{array}{l}\text { 5'-CGAAACGCTTCACTTCCAA-3' } \\
\text { 5'-TGAGCCTATATTGCTGTGGCT-3', }\end{array}$ & 311 & 60 \\
\hline $\mathrm{COX}-2$ & $\begin{array}{l}\mathrm{F} \\
\mathrm{R}\end{array}$ & $\begin{array}{l}\text { 5'-CCTGTGTTCCACCAGGAGT-3' } \\
\text { 5'-GTCCCTGGCTAGTGC TTCAG-3', }\end{array}$ & 249 & 55 \\
\hline$\beta$-actin & $\begin{array}{l}\mathrm{F} \\
\mathrm{R}\end{array}$ & $\begin{array}{l}\text { 5'- TGGAATCCTGTGGCATCCATGAAAC-3' } \\
\text { 5'- TAAAACGCAGCTCAGTAACAGTCCG-3' }\end{array}$ & 349 & 55 \\
\hline
\end{tabular}

\section{Statistical Analysis}

Triplicate experiments were performed throughout this study. All data were presented as the mean \pm Standard Error Minimum (SEM), which were analyzed using the SPSS 22 software. The significant difference between Lipopolysaccharide and treated groups was analyzed by the paired Turkey HSD $(\mathrm{p}<0.05)$.

\section{Phytochemicals Screening}

\section{RESULTS AND DISCUSSION}

Phytochemical screening tests were conducted on secondary metabolites i.e. alkaloids, flavonoids, tannins, saponins, glycosides, steroids that have been extracted with n-hexane solvent can be seen in Table-2.

Table-2: Phytochemicals Screening Result

\begin{tabular}{c|c|c|c|c}
\hline No & Phytochemicals & NESVL & EAESVL & EESVL \\
\hline 1. & Alkaloids & - & - & - \\
\hline 2. & Flavonoids & - & + & + \\
\hline 3. & Tannins & - & + & + \\
\hline 4. & Saponins & - & + & + \\
\hline 5. & Glycosides & - & + & + \\
\hline 6. & Steroids/Triterpenoids & + & - & + \\
\hline
\end{tabular}

Description: $(+)$ positive: contains a class of compounds; (-) negative: does not contain a class of compounds

\section{Nitric Oxide (NO) Production}

The results of examination nitric oxide level on RAW 264.7 cell line with LPS $(1 \mu \mathrm{g} / \mathrm{mL})$ induction and administration of ENSVL, EEASVL, and EESVL can be seen in Fig.-1.

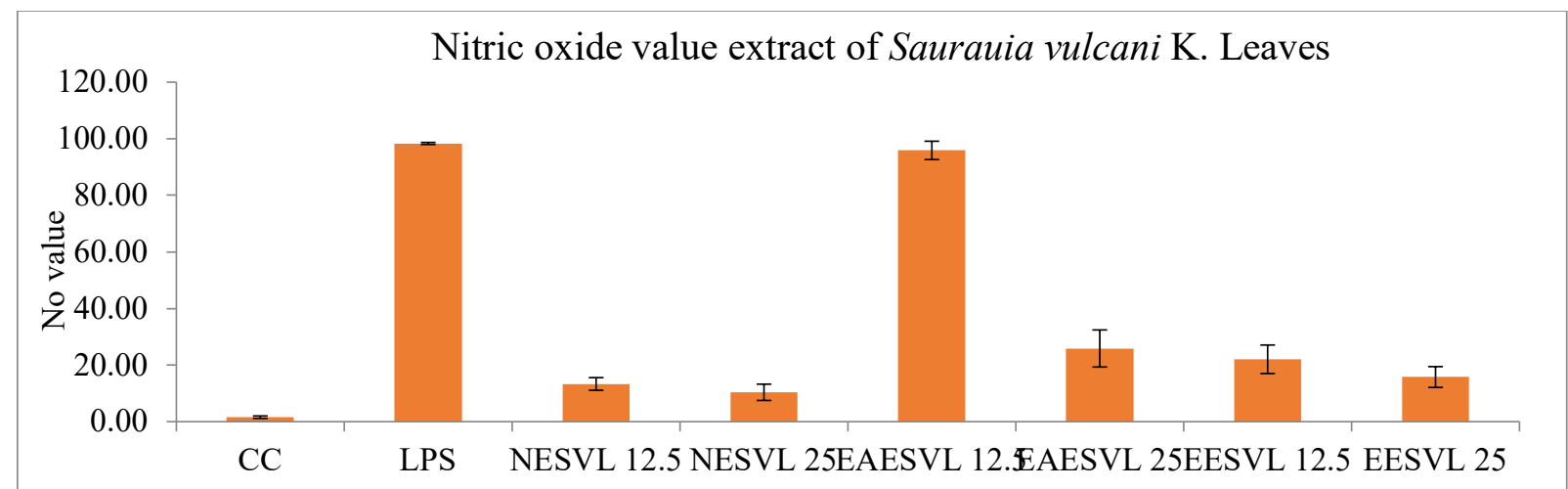

Fig-1: Nitric Oxide Value of extract of Saurauia vulcani K. Leaves. CC: Cell Control; LPS: Lipopolysaccharides; NESVL: n-Hexane Extract of Saurauia vulcani K. Leaves; EAESVL: Ethylacetate Extract of Saurauia vulcani K. Leaves; EESVL: Ethanol Extract of Saurauia vulcani K. Leaves. 
RASĀYAN J. Chem.

Vol. 14 | No. 2 |1378-1383| April - June | 2021

Effects of NESVL, EAESVL, EESVL on The Genes Expression of Cytokines (TNF-A, IL-6, IL-1ß), Inos and COX-2 in LPS-Induced Macrophages

The results of gene expression treated with NESVL, EAESVL, EESVL were analyzed using RT-PCR methods and the results were showed in Fig.-2.

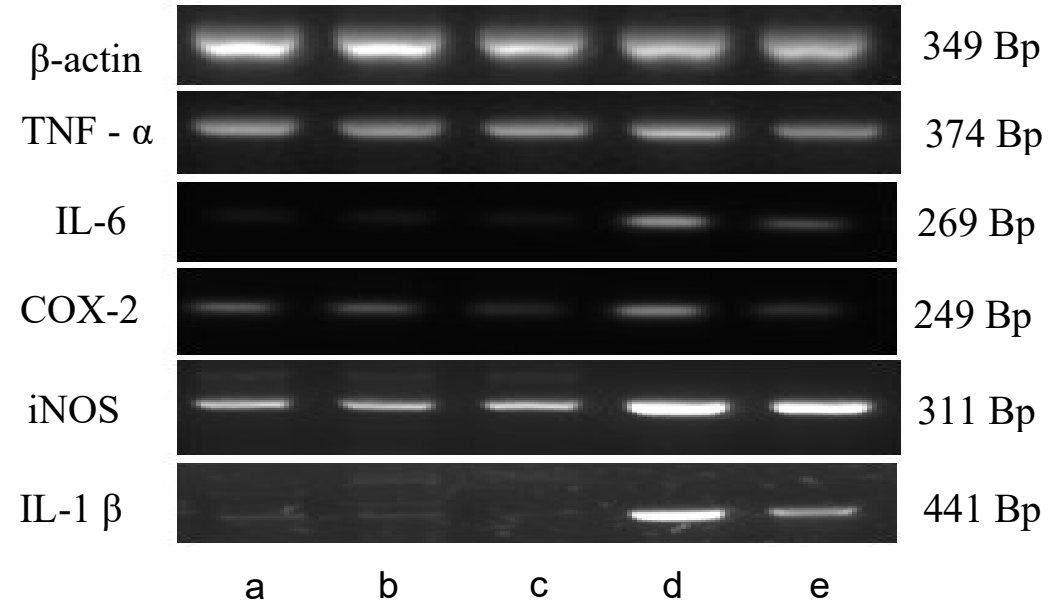

Fig.-2: The effect of extracts on the gene expression in RAW 264.7 cell which induced LPS $1 \mu \operatorname{gmL}^{-1}$ for 6 hours. The total RNAs were isolated, and RT-PCR was performed using the indicated primers in Materials and Methods, (a) EESVL $25 \mu \mathrm{gmL}^{-1}$, (b) EEASVL $25 \mu \mathrm{gmL}^{-1}$, (c) NESVL $25 \mu \mathrm{gmL}^{-1}$, (d) LPS, (e) cells control. $\beta$-actin was used as the internal control. LPS, Lipopolysaccharide; RT-PCR, reverse transcription-PCR; iNOS, Inducible Nitric Oxide Synthase; IL, interleukin; COX-2, Cyclooxygenase-2; Bp, Base Pair.

The results were shown from the value of genes expression toward LPS showed a significant difference with $\mathrm{P}<0.05$ in Table-3.

Table-3: The Value of Genes Expression in RAW 264.7 cells which induced LPS

\begin{tabular}{c|c|c|c|c|c}
\hline \multirow{2}{*}{ Gene } & \multicolumn{5}{|c}{ Mean \pm SEM } \\
\cline { 2 - 6 } & EESVL & EAESVL & NESVL & LPS & Control cell \\
\hline TNF- $\alpha$ & $0.88 \pm 0.003$ & $1.15 \pm 0.005$ & $1.21 \pm 0.005$ & $1.64 \pm 0.003$ & $1.00 \pm 0.00$ \\
\hline IL-6 & $0.55 \pm 0.003$ & $1.64 \pm 0.005$ & $1.23 \pm 0.003$ & $2.12 \pm 0.003$ & $1.00 \pm 0.00$ \\
\hline COX-2 & $0.38 \pm 0.003$ & $0.55 \pm 0.003$ & $0.38 \pm 0.003$ & $2.14 \pm 0.003$ & $1.00 \pm 0.00$ \\
\hline IL-1 $\beta$ & $0.03 \pm 0.003$ & $0.04 \pm 0.003$ & $0.18 \pm 0.003$ & $2.76 \pm 0.003$ & $1.00 \pm 0.00$ \\
\hline iNOS & $0.11 \pm 0.005$ & $0.41 \pm 0.003$ & $0.30 \pm 0.003$ & $1.31 \pm 0.003$ & $1.00 \pm 0.00$ \\
\hline$\beta$-actin & $0.94 \pm 0.003$ & $1.12 \pm 0.005$ & $1.27 \pm 0.003$ & $1.07 \pm 0.003$ & $1.00 \pm 0.00$ \\
\hline
\end{tabular}

Saurauia vulcani Korth leaves are a plant with the family Actinidiaceae used as traditional medicine. Saurauia vulcani Korth Leaves activity as an immunomodulator begins with phytochemical screening tests to determine the content of secondary metabolites contained in simplicia, testing of nitric oxide levels in RAW 264.7 cells line induced by each LPS $1 \mu \mathrm{g} / \mathrm{mL}$, NESVL $(12.5 \mu \mathrm{g} / \mathrm{mL}$ and $25 \mu \mathrm{g} / \mathrm{mL})$, EAESVL $(12.5 \mu \mathrm{g} / \mathrm{mL}$ and $25 \mu \mathrm{g} / \mathrm{mL})$, and EESVL $(12.5 \mu \mathrm{g} / \mathrm{mL}$ and $25 \mu \mathrm{g} / \mathrm{mL})$, further testing of TNF- $\alpha$, IL6 , COX-2, IL-1 $\beta$, and iNOS gene expression.

The results of phytochemicals screening from extract ethyl acetate and ethanol of Saurauia vulcani Korth leaves (EAESVL and EESVL) contains flavonoids, tannins, saponins, glycosides while extract $n$-hexane (NESVL) only contain steroids which seen in table 1. Saurauia vulcani Korth leaves (NESVL, EAESVL, and EESVL) were tested on RAW 264.7 cell lines to determine NO production. RAW 264.7 cell lines induced using LPS experienced an increase in nitrite levels and the administration of extracts decreased nitrite levels, seen at concentrations of $12.5 \mu \mathrm{g} / \mathrm{mL}$ greater nitrite levels and concentrations of $25 \mu \mathrm{g} / \mathrm{mL}$, nitrite levels decreased significantly which means that Saurauia vulcani Korth leaves extract can inhibit NO production. The content of metabolite compounds in leave extract Saurauia vulcani Korth such as flavonoids, saponins, tannins, steroids/triterpenoids, and glycosides can inhibit NO production in RAW cells 264.7. ${ }^{14-19}$ 
RASĀYAN J. Chem.

Vol. 14 | No. 2 |1378-1383| April - June | 2021

Gene expression testing was performed using the RT-PCR method. In this test RAW 264.7 cells were treated with NESVL, EAESVL, and EESVL with a concentration of $25 \mu \mathrm{g} / \mathrm{mL}$ which had been induced by LPS $1 \mu \mathrm{g} / \mathrm{mL}$. The results of gene expression testing show that NESVL, EAESVL, and EESVL can reduce gene expression compared to LPS. Administration of extract can reduce the expression of TNF- $\alpha$, IL- 6 , COX-2, IL-1 $\beta$, and iNOS in RAW 264.7 cells induced by LPS with a density value of each of $1.21 \pm 0.005$; $1.15 \pm 0.005 ; 0.88 \pm 0.003$ on TNF- $\alpha, 1.23 \pm 0.003 ; 1.64 \pm 0.005 ; 0.55 \pm 0.003$ on IL- $6,0.38 \pm 0.003 ; 0.55$ $\pm 0.003 ; 0.38 \pm 0.003$ on COX-2, $0.18 \pm 0.003 ; 0.04 \pm 0.003 ; 0.03 \pm 0.003$ on IL- $1 \beta$, and $0.30 \pm 0.003 ; 0.41$ $\pm 0.003 ; 0.11 \pm 0.005$ on iNOS.

\section{CONCLUSION}

Based on statistical tests conducted using the one-way ANOVA method, the significance value of $<0.05$ was obtained. This means that there are significant differences between the test groups in the experiments conducted. TNF- $\alpha$, IL- 6, COX-2, IL- $1 \beta$, and iNOS are genes that influence the performance of macrophages that influence inflammatory events. The content of secondary metabolites in extracts such as flavonoids and steroids/triterpenoids is thought to be able to inhibit the expression of these genes. This is a strong strategy for the development of extracts as an immunomodulator.

\section{ACKNOWLEDGMENT}

This research was funding by the Ministry of Research and Technology/ National Agency for research and Innovation through the "Hibah Penelitian Dasar Unggulan Perguruan Tinggi" research grant 2018 - 2020.

\section{REFERENCES}

1. U. Sharma, M. Bala, N. Kumar, B. Singh, R. K. Munshi, and S. Bahlearao, Journal of Ethnopharmacology, 141, 918(2012), DOI:10.1016/j.jep.2012.03.027

2. Z. Chen, Z. Danni, Q. Zhu, Q. Yang, Carbohydrate Polymers, 106, 217(2014), DOI: 10.1016/j.carbopol.2014.02.004

3. H. Chon, B. Choi, E. Lee, S. Lee, G. Jeong, Journal of Applied Microbiology, 107, 1586(2009), DOI: $10.1111 / j .1365-2672.2009 .04343 . x$

4. S. Hutahaean, R. D. Banjarnahor, P. Darsini, S. Ilyas, and E. Sabri, Journal of Physics: Conference Series, (2018), DOI:10.1088/1742-6596/1116/5/052030

5. R. O. Situmorang, A. H. Harianja, J. Silalahi, Indonesian Journal of Forestry Research, 2(2), 121(2015), DOI: 10.20886/ijfr.2015.2.2.121-130

6. D. Satria, M. Furqan, S. Hadisahputra, Rosidah, International Journal of Pharmacy and Pharmaceutical Sciences, 7, 73(2015)

7. P. Lestari, Thesis, Faculty of Pharmacy, University of Sumatera Utara, Medan (2013)

8. D. Satria, J. Silalahi, G. Haro, S. Ilyas, P. A. Z. Hasibuan, Asian Pacific Journal of Cancer Prevention., 18(2), 399(2017), DOI:10.22034/apjcp.2017.18.2.399

9. H. Wargner and S. Bladt, 1996, Plant Drug Analysis. A Thin Layer Chromatography Atlas. Second Edition. Springer. Verlin Berlin Helderberg, Germany, pp. 4-6, 99-100, 196, 306, 335

10. Kemkes, RI, 2013, Supplement III. Indonesian herbal pharmacopeia, Edition I, Ministry of health the Republic of Indonesia. Jakarta. pp. 28

11. A. Y. Musa, International Journal of Biochemistry, Biophysics \& Molecular Biology, 2(4), 31(2017), DOI: $10.11648 /$ j.ijbbmb.20170204.12

12. T. A. Peash, S. M. Rahman, A. M. Shoahael, International Journal of Biosciences, 11(1),131(2017), DOI: $10.12692 / \mathrm{ijb} / 11.1 .131-140$

13. N. Auliafendri, Rosidah, Yuandani, S. Suryani, D. Satria, Macedonian Journal of Medical Sciences. 7(1), 24(2019), DOI:10.3889/oamjms.2019.493

14. Yanti, T. E. Pramudito, N. Nurisari, and K. Juliana, American Journal of Biochemistry and Biotechnology, 7(4), 190(2011), DOI:10.3844/ajbbsp.190.195

15. M. Durga, S. Nathiya, and T. Devasena, International Journal of Pharmacy and Pharmaceutical Science, 6(2), 50(2014)

16. S. H. Venkatesha, S. Dudies, B. Astry, and K. D. Moudgil, Fems Phatogens and Disease, 74(6), 59 (2016), DOI:10.1093/femspd/ftw059 


\section{RASĀYAN J. Chem.}

Vol. 14 | No. 2 |1378-1383| April - June | 2021

17. S. A. Adebayo, H. C. Steel, L. J. Shai, J. N. Eloff, Journal of evidence-based Complementary and Alternative Medicine, 22(4), 840(2017), DOI:10.1177/2156587217717417

18. K. Dewi, B. Widyarto, P. P. Erawijantari, W. Widowati, International Journal of Research in Medical Sciences, 3(9), 2303(2017), DOI:10.18203/2320-6012.ijrms20150621

19. R. Fachinan, A. Fagninou, M. P. Nekoua, A. M. Amoussa, M. Adjagba, L. Lagnika, A. Laleye, K. Moutairou, A. Yessoufou, Biomed Research International, 42(5), 265(2017), DOI: $10.1155 / 2017 / 9478048$

[RJC-6075/2020] 